УДК 373.3. (430)

DOI 10.31494/2412-9208-2019-1-1-209-216

\title{
Specifics of content of edication in elementary schools of Germany
}

Особливості змісту освіти в початкових школах Німеччини

Olexandra Kashuba,

Candidate of pedagogical sciences, associate professor

https://orcid.org/0000-0002-5478-2875

lesiakashuba@gmail.com

Tetiana Kravchuk,

Candidate of philologival sciences, associate professor

Тетяна Кравчук,

кандидат фрілологічних наук, доцент

https://orcid.org/0000-0003-1396-4573

tanchik454@gmail.com

Halyna Navolska

Галина Навольська,

Candidate of pedagogical sciences, кандидат педагогічних наук, доцент associate professor

https://orcid.org/0000-0003-4196-0123

navolska9@gmail.com

Ternopil National Volodymyr Hnatiuk

Pedagogical University

2 Maksyma Kryvonosa St., Ternopil, 46000
Тернопільський національний педагогічний університет імені

Володимира Гнатюка

вул. Максима Кривоноса, 2 ,

м. Тернопіль, 46000

Original manuscript received March 17, 2019

Revised manuscript accepted April 21, 2019

\begin{abstract}
The article defines the components of elementary education in Germany considering the specifics of training in modern German school. The challenge for changes in Ukrainian education is the fact that today, unfortunately, the elementary school has become inefficient in comparison with European primary education. To keep up with times, it is necessary to change approaches and the format of training. All this is rises our interest for achievements of foreign scholars. The research is devoted to the problems of implementation of content of education in elementary schools in Germany, where the main purpose of training is the development of students' communication skills. Thus, we see that in the process of studying the peculiarities of the content of elementary school education, an important role is played by increase in the educational time and redistribution of time for learning individual subjects and topics, as well as the broadening the curricula through new material, developing differentiation of tasks, taking into account the emotional and social stability of a child, providing comprehensive development of the personality, focusing on the development of thinking and cognitive abilities of students during the modernization of curricula, programs and textbooks, expanding the scope of the optional subjects. It is obvious that many problems of specific elementary school content of education also require further resolution in
\end{abstract}


Серія: Педагогічні науки. - Вип.1. - Бердянськ : БДПУ, 2019. - 406 с.

Germany. However, the experience of German primary education is of increasing interest in Europe. As for Ukraine, free access to information will allow domestic scientists to carry out an effective comparative analysis, identify those forms and methods that are appropriate to use in the national school environment. Practical value of the work is determined by the fact that the worked out material, the statements and conclusions will facilitate sharing the pedagogical experience. They can be used for writing textbooks and methodic guidances, in the practical activity of elementary school teachers.

Key words: content of education, curriculum, foreign language, elementary school, Germany.

Вступ. Проблема змісту освіти - одне з головних питань теорії та практики навчання в педагогіці. Уявлення про зміст освіти в зарубіжних школах дає середньостатистичне співвідношення предметів у навчальному плані. Бурхливий розвиток Німеччини, її досягнення в галузі науки становлять величезний інтерес для вивчення різних галузей культури, зокрема, системи початкової освіти країни.

Якщо ми звернемося до досвіду початкової школи Німеччини, то побачимо, що навчання набуло більш практичного спрямування, а сам освітній процес зорієнтований на набуття учнями навчальних та життєвих компетентностей. У середині 60-70-x років у ФРН відбулося реформування школи. Результатом змін у змісті освіти стали: посилення наукового характеру навчального матеріалу; орієнтація на розвиток мислення і пізнавальних здібностей учнів у ході модернізації навчальних планів, програм і підручників усіх типів шкіл; розширення мереж факультативних і обов'язкових навчальних дисциплін, запровадження інтегрованих курсів, включення сучасної проблематики в навчальний матеріал традиційних предметів. Численні експерименти і реформи, які проводилися 3 метою вдосконалення системи початкової освіти в Німеччині, свідчать про те, що статусу школи тут надають великого значення. Набутий досвід становить значний інтерес для нашої країни.

Аналіз досліджень і публікацій. Становлення і реформування початкових шкіл Німеччини протягом тривалого часу привертає увагу дослідників. Різноманітним аспектам діяльності початкових шкіл присвячено низку досліджень у німецькій педагогіці (Петерсен, 1997; Родегузер, 1998; Фугр, 2006). У них висвітлюються головні напрямки та організаційні засади діяльності початкових шкіл Німеччини, окреслено її специфіку. Вагомий внесок у вивчення широкого спектру питань, пов'язаних 3 особливостями змісту освіти в початкових школах Німеччини, зокрема в Баварії, зробили (Довгун, 1998; Кашуба, 2005; Підласий,1996). Питання освіти Німеччини вивчали відомі педагоги, зокрема (Абашкіна,1993; Яркіна, 1992). У той же час ряд питань вимагає додаткового вивчення. Зокрема, ретельного дослідження потребує таке явище, як специфіка змісту освіти в початкових школах Німеччини.

Мета статті - виявити особливості реалізації змісту освіти в процесі навчання іноземної мови в початковій школі Німеччини. Відповідно до мети були визначені такі завдання: вивчити і проаналізувати методичну та педагогічну літературу; розглянути 
особливості процесу навчання іноземної мови в початковій школі Німеччини; познайомитися 3 досвідом учителів початкових класів Німеччини з реалізації змісту освіти в процесі навчання іноземної мови.

Методи та методики дослідження. Методологічну основу дослідження становлять теорія наукового пізнання, принципи історизму, науковості, системності, ідея пріоритетної ролі освіти. Для виконання поставлених завдань, досягнення мети використано такі методи дослідження: аналіз і узагальнення інформації вітчизняних та іноземних науково-педагогічних джерел, порівняльно-зіставний аналіз навчальних планів і програм, опрацювання документів та статистичних даних, систематизація та узагальнення результатів дослідження.

Результати та дискусії. Проблема змісту освіти в початкових школах Німеччини реалізується в навчальних планах, програмах, підручниках, розпорядженнях та інструкціях керівних органів. У навчальних планах визначається кількість предметів та годин, які відводяться на їх вивчення.

Програми згідно 3 планами окреслюють обсяг знань 3 усіх обов'язкових предметів, подають перелік розділів і тем, які визначають зміст навчального предмета. Він у початковій школі на сучасному етапі характеризується серйозними змінами в техніці культури читання і письма, комлексному вивченні батьківщинознавства, вивченні математики. Навчальні програми розширюються за рахунок нового матеріалу: вивчення правил дорожнього руху, статеве виховання, а іноді й іноземна мова. Велика увага звертається на "внутрішню диференціацію" (Міністерство культури, 1999:239), яка більше враховує потребу знань в учнів і менше - їх успішність. Значний обсяг навчального матеріалу, застосування нових і вдосконалення традиційних методів навчання, спрямованих на виховання самостійності учнів, індивідуалізацію навчання, вимагають кращого оснащення шкіл технічними засобами і нових організаційних форм. Сюди належать: збільшення числа методичних матеріалів для вчителів і учнів; зменшення кількості учнів у класі і зміна їх кількості в групі залежно від методичних прийомів і теми, що вивчається; збільшення і перерозподіл навчального часу, відведеного на вивчення окремих предметів і тем; поступовий перехід від розподілу на класи до поділу на неоднорідні вікові групи; швидше проходження початкової школи дітьми з вищим рівнем розвитку, причому поряд зі здібностями до навчання рекомендується враховувати, перш за все, емоційну і соціальну стабільність дитини; створення курсів, спрямованих на вирівнювання відставання в розвитку дитини й усунення недоліків розвитку, що заважають учитися.

У педагога немає суворо визначеного плану, який вказує, що і як слід викладати, він часто діє на свій розсуд. Для розвитку індивідуальних здібностей кожної дитини поряд із класною роботою існують форми індивідуального, парного і групового навчання. У Баварії, наприклад, протягом перших двох років викладаються такі предмети, як німецька мова (літературу розглядають як частину мови і не виділяють в окремий предмет), математика, батьківщинознавство, музичне, естетичне виховання і ритміка. 
Серія: Педагогічні науки. - Вип.1. - Бердянськ : БДПУ, 2019. - 406 с.

3 другого класу комплексне викладання іноді охоплює не всі предмети, а лише рідну мову і батьківщинознавство (деяких землях малювання і співи. Поза комплексом вивчаються релігія, математика, письмо і фрізкультура (таблиця 1).

Таблиця 1

Навчальний план для початкової школи (Баден-Вюртемберг) (Фугр,2006:301)

\begin{tabular}{|l|c|c|c|c|}
\hline \multirow{2}{*}{ Навчальний предмет } & \multicolumn{4}{|c|}{ Класи } \\
\cline { 2 - 5 } & 1 & 2 & 3 & 4 \\
\hline Навчання релігії & 2 & 2 & 2 & 2 \\
\hline Німецька мова & 6 & 6 & 7 & 7 \\
\hline Батьківщинознавство & & 3 & 3 & 3 \\
\hline Математика & 4 & 5 & 5 & 5 \\
\hline Образотворче мистецтво & 1 & 2 & 3 & 3 \\
\hline Музика & 1 & 1 & 1 & 1 \\
\hline Спорт & 1 & 1 & 1 & 3 \\
\hline Гімнастика & 2 & 2 & 3 & 3 \\
\hline
\end{tabular}

Форми навчальної діяльності видозмінюються: індивідуальна робота, навчання в парах, групова діяльність. 3 третього класу викладають учителіпредметники, щоб підготувати перехід у середню школу.

Дітей, котрі мають певні проблеми при засвоєнні навичок читання і письма, заохочують додатково. Домашні завдання в Нордрейн-Вестфалії в першому-другому класах мусять бути виконані за 30 хв., 3-4 класів - не більше ніж за 60 хв.

Початкова освіта базується як на сучасності, так і орієнтується на майбутнє. Суспільство, яке постійно розвивається, вимагає подальшого вдосконалення змісту навчання і форм праці. Завдання початкової школи розвинути базу для самостійного мислення учнів, передати досвід формування людських відносин. Тому єдина навчальна програма сприяє розвиткові всіх дітей, додаткові предмети за можливістю показують дітям їх нахили і сприяють їх подальшому розвиткові. Діти, котрі потребують особливої допомоги, отримують підтримку на відповідних, призначених для цього курсах. У навчальних планах знаходять відображення різні форми організації занять, зокрема, поділ класу на групи, диференційоване навчання; заняття, що сприяють подоланню труднощів у засвоєнні навчального матеріалу. Освіта $є$ відкритим, довготривалим процесом, який орієнтується на дію. Люди повинні брати участь у суспільному житті, розв'язувати проблеми, бути відповідальними й обдумувати наслідки власних вчинків. Початкова школа робить вагомий внесок відповідно до їі виховних завдань для самопізнання і пізнання світу дітьми, поступово веде до готовності думати та самостійних і відповідальних вчинків. Вона повинна створити передумови, необхідні для розвитку особистості. Основний зміст, цілі й вимоги, які $€$ педагогічно придатними для подолання життєвих 
ситуацій, повинні знову бути в навчальних дисциплінах початкової школи. Зміст навчання, який $є$ важливим для процесу освіти в початковій школі, відбитий у навчальних планах, які визначають предмети і навчальні галузі. Основними дисциплінами залишаються: німецька мова, математика, праця, мистецтво, музика, спорт, релігія (Фугр,2006:296). 3 усіх предметів учні повинні здобути основні знання, розвинути здібності й готовність до подальшого життя. Сюди належить, перш за все, читання, письмо і рахунок.

Початкова школа в Німеччині охоплює 1-4 класи, а у Бранденбурзі і Берліні - 1-6 класи. У ній учні здобувають загальні знання, вміння та навички і готуються до переходу в середні класи. У 1-4 класах учні опановують техніку читання, письмо, арифрметику (навчальні предмети - німецька мова, математика), відкривають особливості навколишнього світу (природознавство), вивчають музику і мистецтво. У 5-6 класах заплановані такі предмети: німецька мова, друга іноземна мова, фізика, біологія, географрія. історія, мистецтво, музика, фізкультура. Окремі початкові школи в Бранденбурзі організовують навчальний процес за спеціальними навчальними планами (22 школи в Потсдамі працюють за системою Марії Монтессорі). Проект Міністерства освіти, молоді і спорту містить рекомендації щодо вивчення іноземних мов у початковій школі. У школах (24 класи, 500 учнів) вивчають іноземні мови (фрранцузьку, англійську, польську, російську) з 3-го класу. Гессенський закон від 1992 р. пропонував запровадити вивчення англійської мови (у третьому класі) ( Рамкова програма, 2004: 84).

Учителі докладають багато зусиль, щоб діти не відчували різкої різниці при переході в середні класи, щоб не існувало для них ніякого бар'єру. У Рейнлянд-Пфальц, наприклад, у першому-другому класах у дітей розвивається техніка письма і читання, у третьому засвоюються знання німецької мови, математики, релігії та природознавства.

Таблиця уроків, призначена міністром культури, $є$ визначальною для землі Північний Рейн-Вестфалія (таблиця 2.). Саме тут навчання мистецтва дає елементарні знання і навички в техніко-економічній, а також суспільно-політичній галузях. Диференційоване навчання залежно від успішності здійснюється з таких предметів, як математика та рідна мова.

Таблиця 2

Навчальний план для початкової школи

(Північний Рейн-Вестфалія) (Петерсен, 1998: 74)

\begin{tabular}{|c|c|c|c|c|}
\hline Предмет & Класи & & & \\
\hline & 1 & 2 & 3 & 4 \\
\hline Мова & 6 & 7 & 5 & 5 \\
\hline Природознавство & & & 3 & 4 \\
\hline Математика & 4 & 4 & 4 & 4 \\
\hline Фізкультура & 3 & 3 & 3 & 3 \\
\hline Музика & 3 & 4 & 4 & 4 \\
\hline
\end{tabular}


Серія: Педагогічні науки. - Вип.1. - Бердянськ : БДПУ, 2019. - 406 с.

\begin{tabular}{|l|c|c|c|c|}
\cline { 5 - 5 } Мистецтво & & & & \\
\hline Релігієзнавство & 2 & 2 & 3 & 3 \\
\hline Кількість год. на тиждень & $\mathbf{1 8}$ & $\mathbf{2 0}$ & $\mathbf{2 2}$ & $\mathbf{2 3}$ \\
\hline
\end{tabular}

За індивідуальним рівнем успішності школярів змінюються цілі та зміст першого або другого ступеня занять із початкового читання. Школярі повинні бути здатними пояснювати різноманітні тексти, розпізнавати мету; їх читацькі інтереси мають поглиблюватися та розширюватися. Цільові засоби вимагають постійного збільшення читацьких навичок. Заохочення до читання має перевагу над розбором змісту тексту, його композиції та характеру. Вивчені вірші сприяють розвитку пам'яті, навичок зв'язного мовлення, творчо-ігровому спілкуванню та знайомству з мовою. При виборі матеріалу для читання вчитель зважає на різноманіття видів тексту. Він використовує такі, що знайомлять дитину з багатством літератури та мистецтвом мови, сприяють розумінню сучасних і майбутніх життєвих ситуацій, розвивають уміння міркувати. Береться до уваги ствлення до батьківщини, однолітків і християнської моралі.

Якщо навчальні плани для початкової школи в Північному РейніВестфалії розглядаються в рамках директив, то загальноосвітнім цілям надається особливе значення як іноземним районам. У розділі "Цілі навчання в початковій школі" підкреслюється: “У зв'язку 3 цілями виховання початкова школа ставить перед собою завдання ще в ранньому віці активізувати критичне мислення дітей і сприяти елементарній формі “права голосу” (Родегузер, 1998: 6).

Для початкової школи характерний принцип класного навчання, тому що дитина не повністю усвідомлює зміну вчителів певних предметів, бо їй бракує власної точки зору щодо особливостей і методів кожного педагога. "По суті, вона більше потребує поділу на вчителів, ніж старша дитина, котра має до цього особисте, об'єктивне ставлення" (Родегузер,1998:36). Водночас полегшена форма принципу класного навчання полягає в тому, що педагог несе відповідальність за велику частину занять класу і повинен турбуватися про виконання завдань учнями на уроці, адже в першому i другому класах приблизно 2/3 навчального часу проводить один учитель, а в третьому-четвертому повинен викладати не менше двох годин на день.

Підсумовуючи, можна констатувати, що навчальний план для початкових шкіл Німеччини відповідає педагогічним вимогам, а також дидактичній меті, яка стоїть перед кожною школою зокрема. Зміст освіти початкової школи Німеччини передбачає навчити дітей читати, писати, рахувати, логічно мислити, правильно висловлювати свої думки письмово і усно, розуміти навколишні явища (Кашуба,2008:127).

Висновки та перспективи подальших розвідок. Початкова школа ФРН є універсальною за своєю природою, вона увібрала в себе синтез педагогічних надбань деяких країн світу та знаходить оптимальні шляхи розв'язання педагогічних проблем. У початковій школі на заняттях 
учні знайомляться з основними навчальними предметами. 3 цього часу організують спроби орієнтації змісту та форм навчання на індивідуальні здібності й можливості кожного учня. Характер вивчення цих питань вимагає роздумів, одночасного засвоєння різних наук, правильної оцінки потенційних можливостей учнів, тут неможливе застосування традиційних форм організації навчального процесу. А тому кожен учитель опиняється перед необхідністю розв'язувати педагогічні проблеми, які вимагають якісно іншої підготовки, вищої кваліфікації.

Україна стоїть на порозі освітніх реформ, тому вивчення та подальше використання досвіду розвинутих країн викликає особливий інтерес. У боротьбі за реформи нам потрібна підтримка зарубіжних колег. Звичайно, ми не повинні зробити українську шкільну освіту такою, якою вона є, наприклад, у Німеччині. Адже українська освітня реальність вимагає вироблення власного механізму інтеграції здобутків світової педагогічної думки з традиціями національної школи, особливостями національного менталітету.

\section{Література}

1. Абашкіна Н. В. Організація навчально-виховного процесу у вальдорській школі (Німеччина) // Початкова школа. - 1993. - №1 . - С. 41 - 42.

2. Довгун А. О проблемах обучения и воспитания в школах ГДР и воспитание школьников. - 1998. - №6. - С. 76-77.

3. Кашуба О. М. Вивчення іноземних мов у початкових школах Німеччини // Збірник наукових праць: Педагогічні шляхи реалізації загальноєвропейських цінностей у системі освіти України. - Харків, 2005. - С.125 - 129

4. Кашуба О. М. Концепції створення якісно нового підручника з іноземної мови для початкової школи України на основі досвіду педагогів Німеччини // Серія: Педагогіка і психологія. Кримський гуманітарний університет. Випуск 17. Частина 1. Ялта: КГУ, 2008. - С. $124-129$

5. Подласый И. П. Педагогика. - Москва, 1996. - 403 с.

6. Яркина П.Ф. Концепция целостной школы в современной немецкой педагогике // Педагогика. - 1992. — №7-8. - С. 110-116.

7. Führ Ch. Deutsches Bildungswesen seit 1945-1996. - Bonn: Inter Nationes, 1996.-342 s.

8. Petersen J. Bildung in Deutschland. Band 3. - Auer Verlad GmbH, 1998.-250 s.

9. Rahmenrichtlinien für die Grundschule, Deutsch. - Hannover, 2004. - S. 6-67

10. Richtlinien und Lehrpläne für die Grundschule in Nordrhein-Westfalen. Dusseldorf: Henn Verlag, 1999. -311s.

11. Rodehuser F. Epochen der Grundschulgeschichte. - Bochum: Winkler, 1998. $-402 \mathrm{~s}$.

\section{References}

1. Abashkina N. V. Orhanizatsiia navchalno-vykhovnoho protsesu u valdorskii shkoli (Nimechchyna) // Pochatkova shkola. - 1993. - №1 . - S. 41 - 42.

2.Dovhun A. O problemakh obuchenyia y vospytanyia $v$ shkolakh HDR y vospytanye shkolnykov. - 1998. - №6. - S. 76-77.

3. Kashuba O. M. Vyvchennia inozemnykh mov u pochatkovykh shkolakh Nimechchyny // Zbirnyk naukovykh prats: Pedahohichni shliakhy realizatsii zahalnoievropeiskykh tsinnostei u systemi osvity Ukrainy. - Kharkiv, 2005. - S.125 - 129

4.Kashuba O. M. Kontseptsii stvorennia yakisno novoho pidruchnyka $z$ inozemnoi movy dlia pochatkovoi shkoly Ukrainy na osnovi dosvidu pedahohiv Nimechchyny // Seriia: Pedahohika i psykholohiia. Krymskyi humanitarnyi universytet. 
Vypusk 17. Chastyna 1. Yalta: KHU, 2008. - S. $124-129$

5. Podlasbi Y. P. Pedahohyka. - Moskva, 1996. - $403 \mathrm{~s}$.

6. larkyna P.F. Kontseptsyia tselostnoi shkolb v sovremennoi nemetskoi pedahohyke // Pedahohyka. - 1992. — №7-8. - S. 110-116.

7. Führ Ch. Deutsches Bildungswesen seit 1945-1996. - Bonn: Inter Nationes, 1996.-342 s.

8. Petersen J., Bildung in Deutschland. Band 3. - Auer Verlad GmbH, 1998.-250 s.

9. Rahmenrichtlinien für die Grundschule, Deutsch. - Hannover, 2004. - S. 6-67

10. Richtlinien und Lehrpläne für die Grundschule in Nordrhein-Westfalen. Dusseldorf: Henn Verlag, 1999. -311s.

11. Rodehuser F. Epochen der Grundschulgeschichte. - Bochum: Winkler, 1998. $-402 \mathrm{~s}$.

\section{АНОТАЦІЯ}

У статті визначаються складові змісту початкової освіти в Німеччині, розглядається специфріка навчання в сучасній німецькій школі. Викликом для змін в українській освіті є той фракт, що сьогодні, на жаль, початкова школа стала недостатньо ефрективною в порівнянні з європейською. На вимогу часу потрібно змінювати підходи та фрормат навчання.

Усе це обумовлює наш інтерес до здобутків зарубіжних учених. Дослідження присвячено проблемам реалізації змісту освіти в початкових школах Німеччини, де основною метою навчання $\epsilon$ розвиток у школярів здібностей до спілкування. Таким чином, бачимо, що в процесі вивчення особливостей змісту освіти початкової школи важливу роль відіграє збільшення часу $i$ його перерозподіл на вивчення окремих предметів $i$ тем, а також розширення навчальних програм через новий матеріал, розвиток диференціації завдань, урахування емоційної і соціальної стабільності дитини, забезпечення всебічного розвитку особистості, орієнтація на розвиток мислення $i$ пізнавальних здібностей учнів під час модернізації навчальних планів, програм $i$ підручників, розширення мереж фракультативних навчальних дисциплін. Очевидно, що багато проблем особливостей змісту освіти в початкових школах потребують $і$ в Німеччині подальшого розв'язання. Однак досвід німецької початкової освіти викликає все більший інтерес у Європі. Щодо України, то вільний доступ до інформації дозволить вітчизняним ученим здійснити ефрективний порівняльний аналіз, визначити ті фрорми і методи, які доцільно використати в умовах національної школи. Практичне значення роботи визначається тим, що опрацьований матеріал, положення $і$ висновки сприятимуть передачі педагогічного досвіду. Вони можуть бути використані в написанні підручників та методичних посібників, у практичній діяльності учителів початкових шкіл.

Ключові слова: зміст освіти, навчальний план, іноземна мова, початкова школа, Німеччина. 